\title{
THE ROLE OF UNGULATES IN SOIL ZOOCOENOSIS DEVELOPMENT OF THE STEPPE ZONE OF THE URALS
}

\author{
Marina A. Bulgakova ${ }^{1}$, Ekaterina V. Pyatina $^{2}$ \\ ${ }^{1}$ Orenburg State University, Russia \\ e-mail:biosu@mail.ru \\ ${ }^{2}$ Dokuchaev Central Museum of Soil Science, Russia \\ e-mail:kat1977kat@gmail.com
}

Received: 12.02.2019. Revised: 08.05.2019. Accepted: 09.05.2019.

\begin{abstract}
Since the emergence of steppe habitats, ungulates have been their integral part. Daily grazing of wild ungulates had a beneficial effect on soil vegetation and microclimate. Unfortunately, herds of wild horses have vanished and been replaced by livestock. An investigated virgin land was a forb plant community with a predominance of Stipa lessingiana and Festuca valesiaca. As phytocoenosis degraded, the occurrence of Artemisia austriaca increased, and complete replacement of forbs by wormwood steppe was observed. The presented results obtained in the ecosystems of pastures subjected to zoogenic aridisation demonstrate that the agrocoenosis first loses mesophilic components of the Coleoptera fauna (Athous haemorrhoidalis, Calathus erratus, C. melanocephalus, Crypticus quisquilius, Pedinus femoralis, Melanotus rufipes, M. niger, Selatosomus gravidus, Poecilus lepidus, $P$. sericeus, $P$. versicolor. At the same time, dry-steppe species are becoming common, which include Calathus halensis, Cymindis angularis, Harpalus rufipes, Ophonus stictus, Blaps halophila, Gonocephalum granulatum, Platyscelis hypolitha, Agriotes sputator. Therefore, a change in the structure and composition of mesopedofauna occurs through changes in the stand species composition, soil structure under excessive load, and soil dampness during upper soil compression.
\end{abstract}

Key words: biodiversity, ecosystem, mesofauna, monitoring, pasture, steppe

\section{Introduction}

Steppe ecosystems are a complex system of interspecies relationships. Ungulate animals have always formed an integral part of steppe habitats. The daily grazing of wild ungulates caused a beneficial effect on vegetation and microclimate. Unfortunately, livestock has gradually replaced herds of wild horses, which vanished from these habitats. For decades, livestock herds have uncontrollably overgrazed pastures and firmed the upper soil layers. Alteration of phytocoenoses, properties, and soil regimes have caused serious damage to the abundance of soil animal species. There are both an alteration of plant communities and a shift in species dominance in the soil fauna. However, the exclusion of ungulates from the ecosystem is also harmful. The areas with insignificant livestock grazing, and absence of wild ungulates are characterised by uncontrolled accumulation of dead vegetation. Grass form a mechanical barrier that blocks light and creates a greenhouse effect. Steppe invertebrate species prefer open well-warmed areas without which they shift their habitat to favourable areas. These species are replaced by forest and forest-steppe insect species. This disrupts biocoenosis stability. In addition, accumulation of dead steppe plants leads to the development of fires, which, like overgrazing, has a detrimental effect on the ecosystem (Morris, 1973; Nakamura, 1975; Bulgakova \& Bulgakov, 2013).

A balance between two opposing processes may be achieved by successful reintroduction of the Przewalski's horse Equus ferus przewalskii Poliakov, 1881. Steppes are territories where wild ungulates originally lived. For millennia, they had a beneficial effect on biocoenoses. Pinching off apical plant parts leads to tillering of the plants, and manure left on pasture attracts animals, which forms a stable ecosystem with numerous interspecies relationships (Augustine \& Frank, 2001; Rusanov \& Bulgakova, 2016; Bulgakova, 2017).

The purpose of this study is to evaluate the impact of grazing ungulates on the soil properties and fauna.

\section{Material and Methods}

Studies were performed from 2010 to 2018 in areas with quasi-natural vegetation conditionally considered virgin (reference areas) and areas of pastures degraded to different degrees on ordinary chernozems of the true steppe located on the flattened Ural - Sakmara watershed (Fig.). 


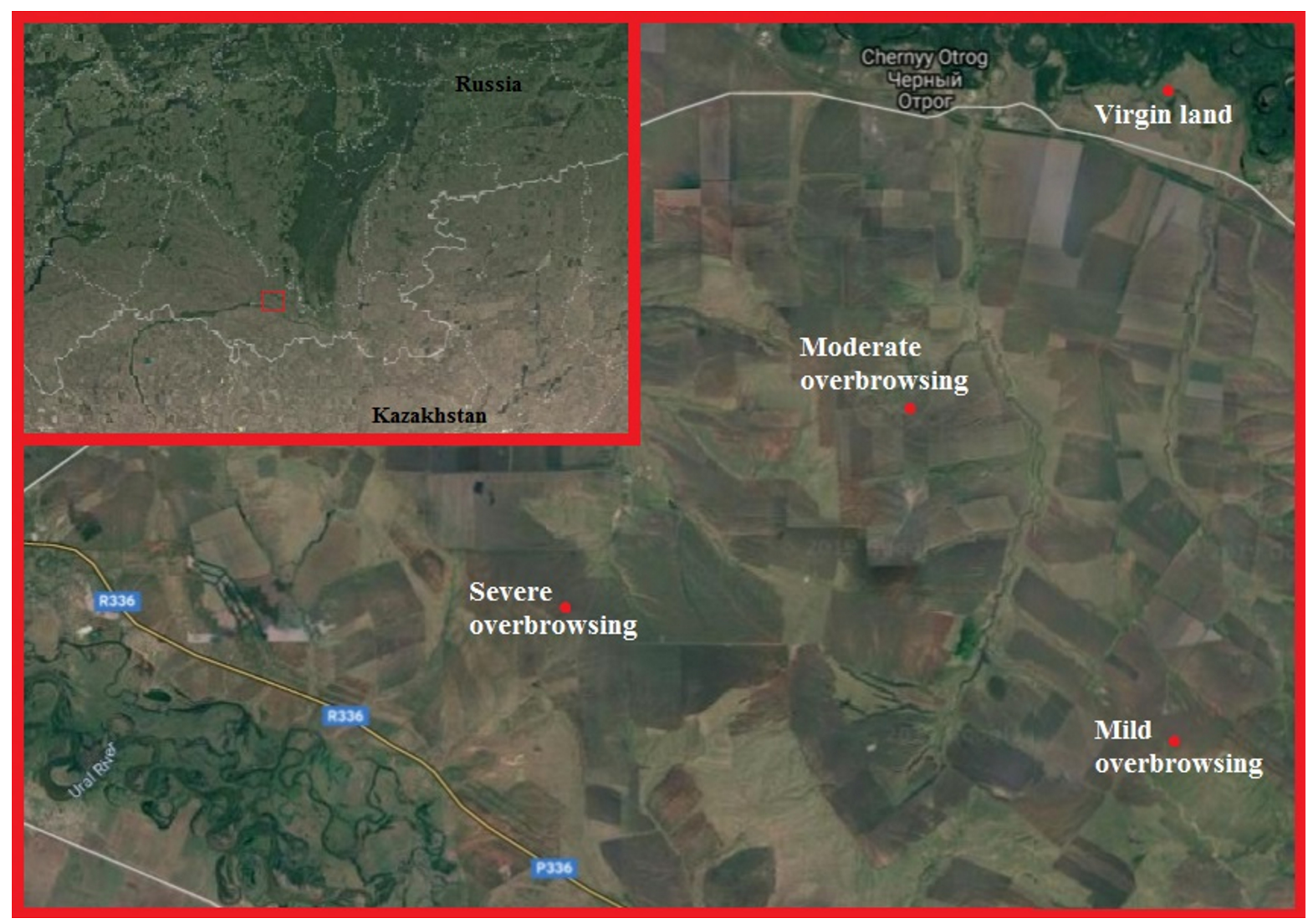

Fig. The location of the experimental sites.

The quasi-natural vegetation of the reference area was represented by the community Stipa lessingiana Trin. et Rupr. + Festuca valesiaca Gaudin with $80-83 \%$ coverage. Although this area was conditionally considered virgin, the sporadic occurrence of Stipa tirsa Stev. and Artemisia austriaca Jacq. indicated that it had been exposed to an insignificant grazing impact. The weakly degraded pasture area was occupied by the community Festuca valesiaca + Stipa lessingiana + Artemisia austriaca with $60-62 \%$ coverage. The moderately degraded area was occupied by the community Festuca valesiaca + Poa bulbosa L. with 48-50\% coverage. The area with the community of Artemisia austriaca + Festuca valesiaca, with 20-25\% coverage, was considered classified as a strongly degraded pasture. The stocks of the aboveground and belowground $(0-20 \mathrm{~cm})$ phytomass in the series from conditional virgin land to strongly degraded pasture decreased by a factor of $37 \mathrm{ton} / \mathrm{km}^{2}$ to $1.9 \mathrm{ton} / \mathrm{km}^{2}$.

The soil properties, composition and geobotanical indicators of the plant cover, and structure and composition of the soil mesofauna have been analysed.

Humidity of the studied soils was determined with a PCE-SMM-1 moisture meter; soil density was measured using a DICKEY-john penetrometer, followed by conversion to $\mathrm{g} / \mathrm{cm}^{3}$; humus was determined with the Tyurin method (Vadunina \& Kor- chagina, 1986). The soil fauna was described using pitfall traps and manual analysis (Ghilarov, 1965).

\section{Results and Discussion}

The data presented in the Table demonstrate that the consistency in pasture land types from virgin steppe to lightly - moderately - strongly overgrazed (degraded) pasture is characterised by a consistent increase in the soil density (by $26 \%$ ), decrease in soil humidity (by $11 \%$ ), increase in open soil areas by $31 \%$, and decrease in the stand length by $44 \%$.

Long-term studies suggest that even intensive grazing does not cause soil organic matter loss. Humus occurs to be sealed and is not consumed for development of the aboveground phytomass. There is no annual ploughing and bringing lower soil layers to the surface (Rusanov \& Bulgakova, 2016).

The population of soil invertebrates includes different functional-coenotic groups, but the most characteristic part of the soil complex is represented by saprophages that account for most soil animals.

Saprophages are closely related to indicators of the composition and abundance of organic matter as a prey item. They are some of the first to respond to anthropogenic influences, and a decrease in their proportion may be an indicator of disturbed ecosystems (Psarev, 2001). 
Table. Average values of main parameters characterising in test areas

\begin{tabular}{|c|c|c|c|c|c|c|c|c|}
\hline Studied areas & 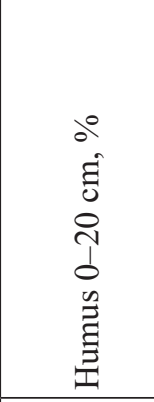 & 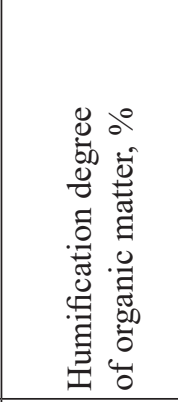 & 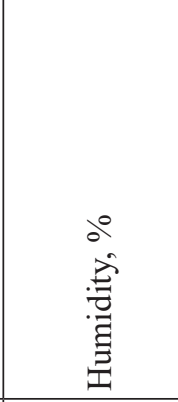 & 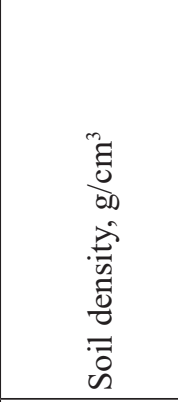 & 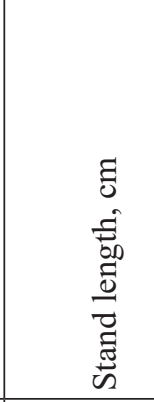 & 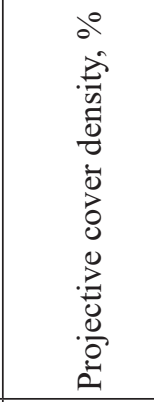 & 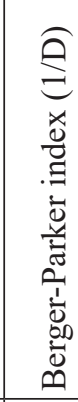 & 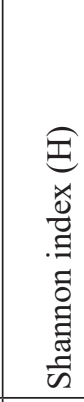 \\
\hline Virgin steppe & $4.7 \pm 0.96$ & $42.2 \pm 2.12$ & $41.6 \pm 3.74$ & $0.94 \pm 0.09$ & $50 \pm 1.54$ & $80 \pm 6.59$ & 2.3 & 2.6 \\
\hline Light overgrazing & $4.6 \pm 0.81$ & $41.6 \pm 1.87$ & $32.1 \pm 1.54$ & $0.99 \pm 0.12$ & $45 \pm 2.87$ & $60 \pm 4.31$ & 3.1 & 2.0 \\
\hline Moderate overgrazing & $4.4 \pm 0.54$ & $38.0 \pm 3.89$ & $24.7 \pm 1.69$ & $1.14 \pm 0.21$ & $37 \pm 3.32$ & $50 \pm 4.89$ & 3.9 & 2.2 \\
\hline Strong overgrazing & $4.1 \pm 0.89$ & $37.0 \pm 2.92$ & $19.3 \pm 1.04$ & $1.28 \pm 0.26$ & $22 \pm 2.87$ & $25 \pm 3.02$ & 5.4 & 1.8 \\
\hline
\end{tabular}

The processes occurring in steppe ecosystems under the influence of ungulate animals cause changes in the fauna structure. Thus, we found extinction of rare species, such as Dorcadion carinatum (Pallas, 1771), D. glycyrrhizae (Pallas, 1774), Meloe erythrocnemus (Pallas, 1782), Calathus erratus (C.R. Sahlberg, 1827), C. melanocephalus (Linnaeus, 1758), Poecilus lepidus (Leske, 1785), P. sericeus (Fischer von Waldheim, 1824), P. versicolor (Sturm, 1824), Melanotus rufipes (Herbst, 1784), M. niger (Fabricius, 1792).

There is a predominance of dry-steppe species (Calosoma investigator (Illiger, 1798), Amphimallon solstitialis (Linnaeus, 1758), Gonocephalum granulatum (Fabricius, 1791), Platyscelis hypolitha (Pallas, 1781)) whose proportion increases many folds. In severely degraded areas, one or two dry-steppe species most often predominate, with their numbers exceeding several hundred folds the normal values. The results we obtained are similar to those obtained for pasture ecosystems of Hungary, Mongolia and America (Carne, 1956; Ádám, 1986; Summerlin et al., 1993).

Pasture load that exceeds the soil ecological capacity provokes a sharp decrease in the bio-productivity of pasture ecosystems and biodiversity of the species composition of plants and soil invertebrates as well as repacking of the upper humus horizon of chernozems under knocked down plant aggregations. Deterioration of the productive properties of agricultural landscapes should be considered as degradation of the steppe geographical zone because steppe landscapes account for most pasture ecosystems.

A leading role in restoration of pasture areas is played by reasonable grazing of livestock or resting of the area populated exclusively by wild ungulates.

\section{References}

Ádám L. 1986. Beetles (Coleoptera) inhabiting sheep droppings in dry pastures of Hungary. Folia Entomologica Hungarica 47: 5-12.

Augustine D.J., Frank D.A. 2001. Effects of migratory grazers on spatial heterogeneity of soil nitrogen properties in a grassland ecosystem. Ecology 82(11): 3149-3162. DOI: 10.1890/0012-9658(2001)082[3149:EOMGOS]2.0.CO;2

Bulgakova M.A. 2017. Materials of beetles (Coleoptera) agrocoenoses Orenburg steppe. Modern Problems of Science and Education 3: 133-140. [In Russian]

Bulgakova M.A., Bulgakov E.A. 2013. Zoological monitoring of pasture ecosystems of the Orenburg Cis-Urals. Agrarian Bulletin of the Urals 2: 43-45. [In Russian]

Carne P.B. 1956. An ecological study of the pasture scarab. Aphodius howitti Hope. Australian Journal of Zoology 4(3): 259- 314. DOI: 10.1071/ZO9560259

Ghilarov M.S. 1965. Zoological Methods of Soil Diagnosis. Moscow: Nauka. 275 p. [In Russian]

Morris M.G. 1973. The Effects of Seasonal Grazing on the Heteroptera and Auchenorhyncha (Hemiptera) of Chalk Grassland. Journal of Applied Ecology 10(3): 761-780. DOI: $10.2307 / 2401868$

Nakamura Y. 1975. Decomposition of organic materials and soil fauna in pasture. 2. Disappearance of cow dung. Pedobiologia 15: 129-132.

Psarev A.M. 2001. Succession of the beetle assemblage in cow and horse dung on mountain pastures. Tethys Entomological Research 3: 125-130.

Rusanov A.M., Bulgakova M.A. 2016. Composition and abundance of soil macrofauna in pasture ecosystems of the steppe zone of the Urals. Russian Journal of Ecology 47(1): 68-73. DOI: 10.1134/S1067413616010136

Vadunina A.F., Korchagina Z.A. 1986. Methods of research of physical properties and soil. Moscow: Agropromizdat. 256 p. [In Russian]

Summerlin J.W., Fincher G.T., Hunter J.S., Beerwinkle K.R. 1993. Seasonal distribution and diel flight activity of dung-attracted histerids in open and wooded pastures in East-central Texas. Southwestern Entomologist 18(4): 251-261. 


\title{
ЗНАЧЕНИЕ КОПЫТНЫХ ЖИВОТНЫХ В ФОРМИРОВАНИИ ПОЧВЕННЫХ ЗООЦЕНОЗОВ СТЕПНОЙ ЗОНЫ УРАЛА
}

\author{
М. А. Булгакова ${ }^{1}$, Е. В. Пятина \\ ${ }^{1}$ Оренбургский государственный университет, Россия \\ e-mail:biosu@mail.ru \\ ${ }^{2}$ Центральный музей почвоведения имени В.В. Докучаева, Россия \\ e-mail:kat1977kat@gmail.com
}

С момента возникновения степных ареалов обитания неотъемлемым их компонентом являлись копытные животные. Ежедневный выпас диких копытных благотворно сказывался на растительности и микроклимате почв. К сожалению, в настоящее время существовавшие ранее стада диких лошадей исчезли, и на смену им пришел выпас домашнего скота. Целинный участок исследования характеризовался разнотравным растительным сообществом с преобладанием Stipa lessingiana и Festuca valesiaca. По мере возрастания деградации в фитоценозе отмечалось увеличение встречаемости Artemisia austriaca и полная замена разнотравья на полынную степь. Представленные в статье результаты, полученные по экосистемам пастбищ подверженных зоогенной аридизации, подтверждают, что в первую очередь агроценоз лишается мезофильных компонентов колеоптерофауны (Athous haemorrhoidalis, Calathus erratus, C. melanocephalus, Crypticus quisquilius, Pedinus femoralis, Melanotus rufipes, M. niger, Selatosomus gravidus, Poecilus lepidus, P. sericeus, P. versicolor). В то же время получают распространение сухостепные виды, среди которых Calathus halensis, Cymindis angularis, Harpalus rufipes, Ophonus stictus, Blaps halophila, Gonocephalum granulatum, Platyscelis hypolitha, Agriotes sputator. Таким образом, через изменение видового состава травостоя, структуры почвы при чрезмерной нагрузке, влажности почвы при уплотнении ее верхних слоев происходит изменение в структуре и составе мезопедофауны.

Ключевые слова: биоразнообразие, мезофауна, мониторинг, пастбище, степь, экосистема 